\title{
Genes involved in arsenic transformation and resistance associated with different levels of arsenic-contaminated soils Lin Cai ${ }^{\dagger 1}$, Guanghui Liu ${ }^{\dagger 1}$, Christopher Rensing ${ }^{2}$ and Gejiao Wang*1
}

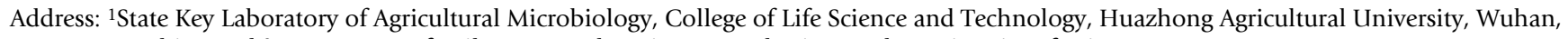
430070, PR China and 2Department of Soil, Water and Environmental Science, The University of Arizona, Tucson, AZ 85721, USA

Email: Lin Cai -cl811022@hotmail.com; Guanghui Liu - newred66@hotmail.com; Christopher Rensing - rensingc@ag.arizona.edu; Gejiao Wang* - gejiaow@yahoo.com.cn

* Corresponding author †Equal contributors

Published: 8 january 2009

BMC Microbiology 2009, 9:4 doi:10.1/86/|47|-2/80-9-4
Received: 28 June 2008

Accepted: 8 January 2009

This article is available from: http://www.biomedcentral.com/I47I-2/80/9/4

(C) 2009 Cai et al; licensee BioMed Central Ltd.

This is an Open Access article distributed under the terms of the Creative Commons Attribution License (http://creativecommons.org/licenses/by/2.0), which permits unrestricted use, distribution, and reproduction in any medium, provided the original work is properly cited.

\begin{abstract}
Background: Arsenic is known as a toxic metalloid, which primarily exists in inorganic form $[\mathrm{As}(\mathrm{III})$ and $\mathrm{As}(\mathrm{V})]$ and can be transformed by microbial redox processes in the natural environment. As(III) is much more toxic and mobile than $\mathrm{As}(\mathrm{V})$, hence microbial arsenic redox transformation has a major impact on arsenic toxicity and mobility which can greatly influence the human health. Our main purpose was to investigate the distribution and diversity of microbial arsenite-resistant species in three different arsenic-contaminated soils, and further study the As(III) resistance levels and related functional genes of these species.
\end{abstract}

Results: A total of 58 arsenite-resistant bacteria were identified from soils with three different arsenic-contaminated levels. Highly arsenite-resistant bacteria (MIC $>20 \mathrm{mM}$ ) were only isolated from the highly arsenic-contaminated site and belonged to Acinetobacter, Agrobacterium, Arthrobacter, Comamonas, Rhodococcus, Stenotrophomonas and Pseudomonas. Five arsenite-oxidizing bacteria that belonged to Achromobacter, Agrobacterium and Pseudomonas were identified and displayed a higher average arsenite resistance level than the non-arsenite oxidizers. 5 aoxB genes encoding arsenite oxidase and $5 I$ arsenite transporter genes [ 18 arsB, 12 ACR3 $(I)$ and $2 I$ ACR3(2)] were successfully amplified from these strains using PCR with degenerate primers. The aoxB genes were specific for the arsenite-oxidizing bacteria. Strains containing both an arsenite oxidase gene (aoxB) and an arsenite transporter gene (ACR3 or arsB) displayed a higher average arsenite resistance level than those possessing an arsenite transporter gene only. Horizontal transfer of $A C R 3(2)$ and arsB appeared to have occurred in strains that were primarily isolated from the highly arsenic-contaminated soil.

Conclusion: Soils with long-term arsenic contamination may result in the evolution of highly diverse arsenite-resistant bacteria and such diversity was probably caused in part by horizontal gene transfer events. Bacteria capable of both arsenite oxidation and arsenite efflux mechanisms had an elevated arsenite resistance level. 


\section{Background}

The toxin arsenic in soil and aqueous environments is considered as one of the prominent environmental causes of cancer mortality in the World, especially in Bangladesh, India and China. In recent years, chronic intake of groundwater with high levels of arsenic has caused endemic arsenicosis in several provinces of China and new cases of arsenicosis are continuously emerging [1]. Developing efficient and environment-friendly technologies to remove arsenic from soil and water systems is of great importance to many countries including China. Bioremediation of heavy or toxic metal contaminated sites has been often shown to be more efficient than chemical and physical methods, especially when stimulating indigenous microbial communities [2].

Bacteria have developed different strategies to transform arsenic including arsenite oxidation, cytoplasmic arsenate reduction, respiratory arsenate reduction, and arsenite methylation [3]. The primary role of some of these transformations is to cope with arsenic toxicity. Arsenite-oxidizing bacteria oxidize arsenite [As(III)] to arsenate $[\operatorname{As}(\mathrm{V})]$ which in many cases is considered primarily a detoxification metabolism since $\mathrm{As}(\mathrm{V})$ is much less toxic than $\mathrm{As}(\mathrm{III})$. In addition, $\mathrm{As}(\mathrm{V})$ is negatively charged and can be easily adsorbed, thus such bacteria have been used in batch reactors together with immobilizing material for removing arsenic from waste water $[4,5]$.

As(III) oxidation has been identified in various bacteria including Pseudomonas [6], Alcaligenes [7], Thiomonas [8], Herminiimonas [9], Agrobacterium [10], and Thermus [11]. Some of these bacteria were able to use As(III) as the sole electron donor and grew as lithotrophs. However, characterized heterotrophic arsenite-oxidizing bacteria have not been shown to gain energy through arsenite oxidation and probably use As(III) oxidation as a detoxification mechanism. Arsenite oxidation was catalyzed by a periplasmic arsenite oxidase. This enzyme contains two subunits encoded by the genes aoxA/aroB/asoB (small Fe-S Rieske subunit) and aoxB/aroA/asoA (large Mo-pterin subunit) respectively [12-14]. Recently aoxB-like sequences have been widely found in different arsenic contaminated soil and water systems [15].

Two families of arsenite transport proteins responsible for As(III) extrusion, ArsB and Acr3p, have been shown to confer arsenic resistance $[12,16,17]$. The founding member of the ArsB family, ArsB from E. coli, has been extensively characterized and shown to be a $45 \mathrm{kDa}$, inner membrane protein with 12 transmembrane helices $[18,19]$. Either ArsB alone or in association with ArsA catalyzes the extrusion of arsenite and antimonite from cells [20]. In most cases, ars $B$ is co-transcribed with ars $C$ encoding an arsenate reductase. It has been suggested that evo- lution and horizontal gene transfer (HGT) of both the ArsB and the ArsC family may have happened simultaneously in microbial evolution [12]. In many cases, As(III) is taken up by aquaglyceroporins [21] and extruded by ArsB [22].

Members of Acr3p transporters showed a function similar to ArsB, but the two proteins have no significant sequence similarity. Even though Acr3p is much less characterized, it has been reported to be present in more phylogenetically distant species than ArsB. Acr3p could be divided into two subfamilies, Acr3(1)p and Acr3(2)p, based on their phylogenetic dissimilarities $[16,23]$. Acr3p appeared to be more specific and transported only arsenite but not antimonite [24,25], except that Acr3p of Synechocystis was able to transport both arsenite and antimonite [26]. The arsenite transporter gene arsB, ACR3(1) and ACR3(2) have been identified in various soil bacteria [16]. However, a correlation between genotype and arsenite resistance level has not been found yet.

The impact of microbial arsenite oxidation and arsenate reduction were reported to influence environmental arsenic cycles [27]. Understanding the diversity and distribution of indigenous bacterial species in arsenic-contaminated sites could be important for improvement of arsenic bioremediation. Microbial species with arsenic biotransforming capabilities had so far not been evaluated in soil systems in China. The objectives of this study were: (1) Study the distribution and diversity of arseniteresistant and arsenite-oxidizing bacteria in soils with different arsenic-contaminated levels; (2) Investigation of the different arsenite oxidase and arsenite transporter genes and attempt to correlate their presence to the arsenic resistance level of these bacteria.

\section{Results \\ Distribution and diversity of arsenite-resistant bacteria in soils with different levels of arsenic}

Analysis of microbial species and diversity of arseniteresistant bacteria were performed in 4 soil samples with high (TS), intermediate (SY) and low (LY and YC) levels of arsenic contamination. A total of 230 arsenite-resistant bacteria were obtained and 14 of them showed arsenite oxidizing abilities. Based on analyses of colony morphologies and 16S rDNA-RFLP, a total of 58 strains were obtained including 5 arsenite-oxidizing bacteria.

Nearly full-length 16S rDNA sequences were used for bacterial identification. Among the analyzed 58 strains, 20 showed 100\% nucleotide identities, 33 had 99\% identities, 3 (Acinetobacter sp. TS42, Janthinobacterium sp. TS3, and Delftia sp. TS40) had 98\% identities and 2 (Acinetobacter sp. TS11, and Acinetobacter sp. TS39) had 97\% identities to sequences deposited in GenBank. Phylogenetic 
analysis divided the 58 strains into 23 genera belonging to 5 major bacterial lineages: $\alpha$-Proteobacteria (5 strains, 2 genera), $\beta$-Proteobacteria (15 strains, 6 genera), $\gamma$-Proteobacteria ( 22 strains, 6 genera), Firmicutes ( 5 strains, 2 genera) and Actinobacteria (11 strains, 7 genera) (Fig. 1).

Among the 58 strains, 45 were isolated from the highly arsenic-contaminated soil (TS1-TS45), 8 were from the intermediate arsenic-contaminated soil (SY1-SY8) and 5 from the low arsenic-contaminated soils (LY1-LY4 and YC1) (Fig. 1). Acinetobacter, Delftia, Arthrobacter, Microbacterium, Aeromonas, Acidovorax, Ensifer, Janibacter, Janthinobacterium, Klebsiella, Kocuria, Micrococcus, Shewanella and Thauera were identified from the highly arsenic-contaminated TS soil only. Achromobacter and Williamsia were specific for the SY site. Exiguobacterium particularly existed in the LY/YC sites. Comamonas, Pseudomonas and Stenotrophomonas were identified from both the TS and SY sites. Agrobacterium, Rhodococcus and Bacillus were identified from both the TS and LY/YC sites. Acinetobacter, Comamonas, Pseudomonas, Stenotrophomonas, Delftia, Agrobacterium and Bacillus were the major arsenite-resistant bacteria in all the analyzed soil samples $(37 / 58=64 \%)$.

\section{Arsenite-oxidizing bacteria were phylogentically distant} Five arsenite-oxidizing bacteria were identified including Achromobacter sp. SY8 ( $\beta$-Proteobacteria), Agrobacterium spp. TS43, TS45, LY4 ( $\alpha$-Proteobacteria), and Pseudomonas sp. TS44 ( $\gamma$-Proteobacteria) (Fig. 1, square black mark). All of them were heterotrophic since they could not use $\mathrm{CO}_{2}$ as the sole carbon source and also could not grow with arsenite as the sole electron donor (data not shown). The $16 \mathrm{~S}$ rDNA identities of these strains were analysed and compared to the following related arsenite-oxidizing bacteria. Achromobacter sp. SY8 shared 98\% 16S rDNA identity to Achromobacter sp. NT10 (GenBank accession no. AY027500) [28]. Agrobacterium spp. TS43, TS45, LY4 showed 99\%, 98\% and 99\% 16S rDNA identities to Agrobacterium sp. 5A (GenBank accession no. AF388033) [29] respectively. The $16 \mathrm{~S}$ rDNA identity between Pseudomonas sp. TS44 and Pseudomonas putida strain OS-5 was $97 \%$ (GenBank accession no. AY952321) [30].

\section{Arsenite resistance levels of arsenite-resistant bacteria vary greatly}

The MIC range for arsenite of the 58 strains was from 2 $\mathrm{mM}$ to $34 \mathrm{mM}$ (Fig. 1). The numbers of the strains with MIC values $\geq 2 \mathrm{mM}, \geq 5 \mathrm{mM}, \geq 10 \mathrm{mM}, \geq 15 \mathrm{mM}, \geq 20 \mathrm{mM}$, $\geq 25 \mathrm{mM}$ and $\geq 30 \mathrm{mM}$ were 58,48, 33, 25, 17, 5 and 2 respectively. Certain correlations were found between the arsenite resistance levels, the bacterial species and soils with different arsenic-contaminated levels: (i) All of the 5 strains belonging to Firmicutes showed a very low MICs [Bacillus spp. TS2 (3 mM), TS27 (5 mM), YC1 (3 mM), LY2 (3 mM) and Exiguobacterium sp. LY3 (3 mM)]; (ii)
Among the strains belonging to Pseudomonas or Agrobacterium, the MICs of arsenite oxidizers were higher than the non-arsenite oxidizers [Pseudomonas sp. TS44 (23 mM) vs Pseudomonas spp. TS5 (9 mM), TS9 (6 mM), SY4 (5 mM), SY6 (3 mM), SY7 (7 mM); Agrobacterium spp. TS43 (25 $\mathrm{mM}), \mathrm{TS} 45$ (20 mM), LY4 (20 mM) vs Agrobacterium sp. TS8 ( $8 \mathrm{mM})$ ]; (iii) The average MIC of the 5 arsenite oxidizers $(20 \mathrm{mM})$ was higher than the 53 non-arsenite oxidizers (12 mM); (iv) A total of 12 highly arsenite-resistant bacteria [Acinetobacter spp. TS6, TS14, TS23 and TS42, Arthrobacter sp. TS22, Comamonas spp. TS37 and TS38, Rhodococcus sp. TS21, Stenotrophomonas spp. TS15 and TS23 and 2 arsenite oxidizers (Agrobacterium sp. TS43 and Pseudomonas sp. TS44)] whose MICs exceeded $20 \mathrm{mM}$ were only obtained from highly arsenic-contaminated TS soil; (v) Only intermediate ( $10 \mathrm{mM}<\mathrm{MICs} \leq 20 \mathrm{mM}$ ) and low (MICs $\leq 10 \mathrm{mM}$ ) MIC levels of arsenite-resistant bacteria were identified from the intermediate and low arsenic-contaminated soils; (vi) Strains of the highly arsenic-contaminated TS site had higher arsenite resistance levels (average MIC $=14 \mathrm{mM}$ ) than the strains of the intermediate (average $\mathrm{MIC}=11 \mathrm{mM}$ ) and low arsenic soils (average $\mathrm{MIC}=8 \mathrm{mM}$ ).

\section{Identification and distribution of the arsenite oxidase gene aoxB and arsenite transporter genes $\operatorname{ars} B, A C R 3(1)$ and ACR3(2)}

A total of 5 arsenite oxidase genes and 51 arsenite transporter genes were successfully amplified from 38 strains using PCR with degenerate primers. The ACR3(1) and $A C R 3(2)$ were amplified in strains of the high and intermediate arsenic-contaminated soils only. In contrast, aoxB and $\operatorname{ars} B$ were found in strains isolated from all three kinds of arsenic-contaminated environments (Fig. 1). Strains containing both an arsenite oxidase gene (aoxB) and an arsenite transporter gene ( $A C R 3$ or ars $B$ ) showed a higher average arsenite resistance level than the strains possessing arsenite transporter genes only [aoxB/ACR3 $(20.25 \mathrm{mM}) \approx \operatorname{aoxB} / \operatorname{arsB}(20 \mathrm{mM})>\operatorname{arsB} / A C R 3(14.29$ $\mathrm{mM}) \approx A C R 3(14.13 \mathrm{mM})>\operatorname{ars} B(10.1 \mathrm{mM})]$.

The $a \circ x B$ sequences were amplified from all of the five arsenite oxidizers. No aoxB sequences were amplified from any of the 53 non-arsenite oxidizers. The deduced amino acid sequence of $a \circ x B$ from Achromobacter sp. SY8 showed 95\% identity to AoxB from Achromobacter sp. NT10 (GenBank accession no. ABD72610) [15]. The deduced AoxBs from Agrobacterium spp. TS43, TS45, and LY4 displayed 95\%, 96\%, and 95\% identities to AoxB of Agrobacterium tumefaciens 5A (GenBank accession no. ABB51928) [31], and 94\%, 96\%, and 95\% identities to AoxB from Rhizobium sp. NT26 (GenBank accession no. AAR05656) [14] respectively. The identity of AoxBs between Pseudomonas sp. TS44 and Alcaligenes faecalis NCIB 8687 was only 61\% (Fig. 2). Comparison between 


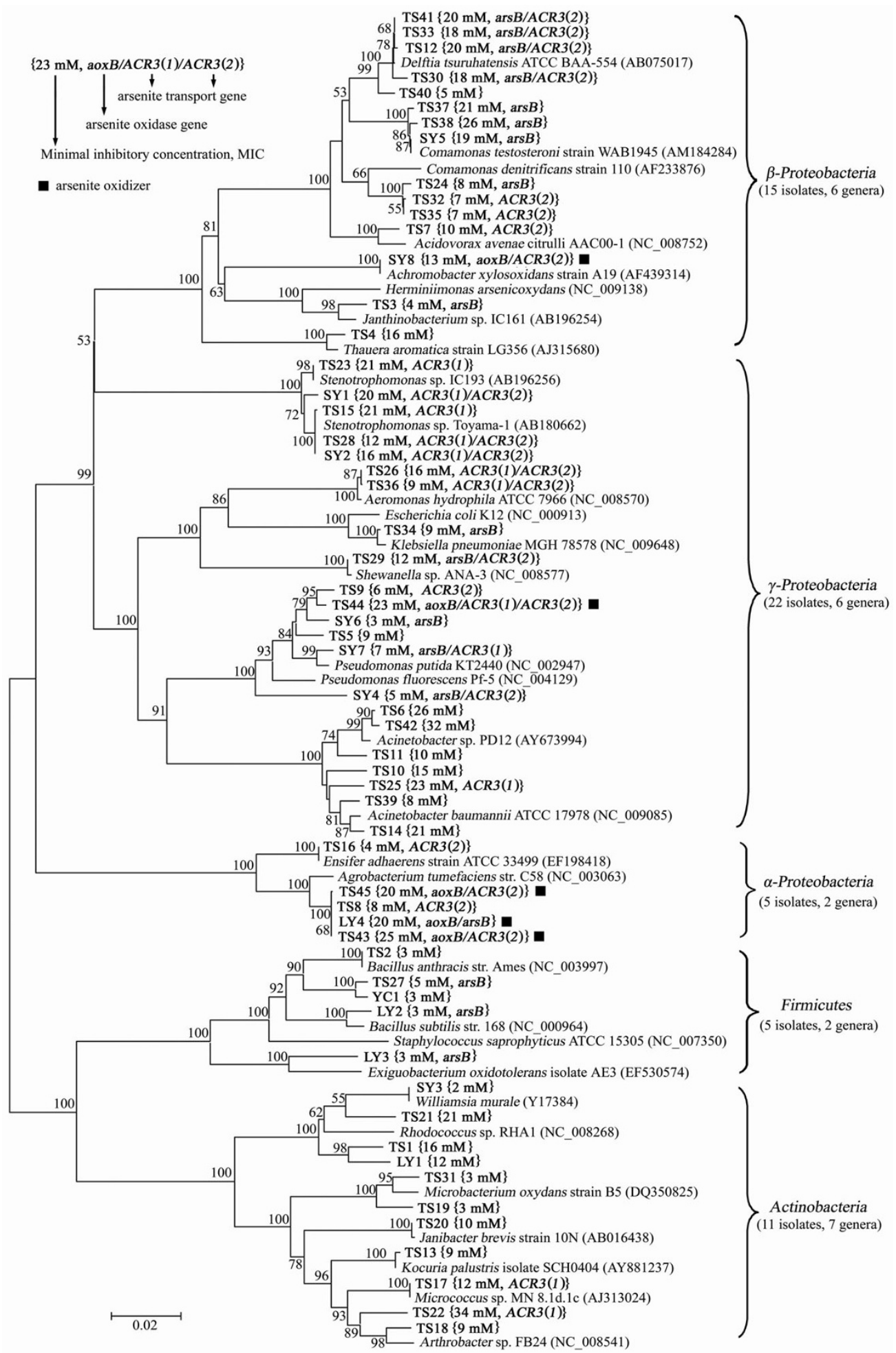

\section{Figure I}

I 6S rRNA phylogenetic tree, MICs, and related genes. I6S rRNA gene ( /400 bp) phylogenetic analysis, MICs, and related genes of arsenite-resistant bacteria identified in soils with high (TS), intermediate (SY) and low (LY/YC) levels of arsenic contamination. Sequences in this study are in bold type and bootstrap values over $50 \%$ are shown. The scale bar 0.02 indicates $2 \%$ nucleotide sequence substitution. 


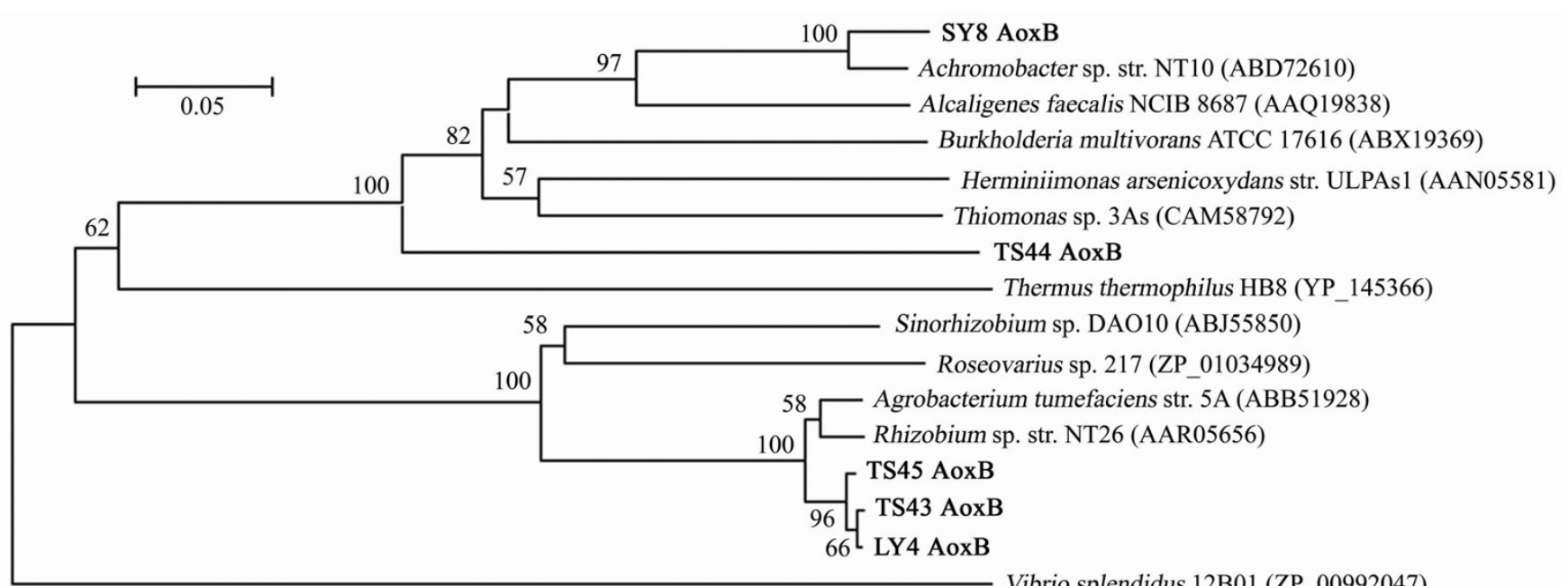

Figure 2

Phylogenetic tree of arsenite oxidase (AoxB). Phylogenetic analysis of the deduced amino acid sequences $(\sim 160$ aa) of aoxB genes. Sequences in this study are in bold type and bootstrap values over $50 \%$ are shown. The scale bar 0.05 means $5 \%$ aa sequence substitution.

16S rDNA and deduced AoxB phylogenetic trees indicated that their evolutionary relationship was similar.

Analyses of arsenite transporter genes using the BlastX algorithm showed proteins with $71 \%-80 \%$ aa identities that contained 2 ArsB and 6 Acr3(2)p, 81\%-90\% aa identities had 10 ArsB, 5 Acr3(1)p and 11 Acr3(2)p, aa identities over 90\% included 6 ArsB, 7 Acr3(1)p and 4 Acr3(2)p. The $\operatorname{ars} B, A C R 3(1)$, and $A C R 3(2)$ were amplified from both the arsenite oxidizers and non-arsenite oxidizers. The strains containing 2 arsenite transporter genes simultaneously were Pseudomonas sp. SY7 [arsB and ACR3(1)], Shewanella sp. TS29, Delftia spp. TS12, TS30, TS33, TS41 and Pseudomonas sp. SY4 [arsB and ACR3(2)], Stenotrophomonas spp. TS28, SY1, SY2, Aeromonas spp. TS26, TS36 and Pseudomonas sp. TS44 [ACR3(1) and ACR3(2)] (Fig. 1). Phylogenetic analysis of ArsB, Acr3(1)p and Acr3(2)p showed a clear separation of the Acr3p and ArsB clusters (Fig. 3). The Acr3p cluster was further divided into two phylogenetic groups, Acr3(1)p and Acr3(2)p. The ArsB cluster was formed by 18 sequences from $\beta$-, $\gamma$-Proteobacteria and Firmicutes; The Acr3(1)p group had 12 sequences from $\gamma$-Proteobacteria and Actinobacteria; The Acr3(2)p group contained 21 sequences from $\alpha-, \beta$, and $\gamma$-Proteobacteria (Fig. 3 ).

\section{Horizontal transfer of arsenite transporter genes may have occurred with ACR3(2) and arsB}

The arsenite oxidase gene aoxB appeared to be vertically transferred when comparing the phylogeny of 16S rRNA genes with those encoding aoxB. In contrast, certain inconsistency occurred when comparing phylogenetic trees based on 16S rRNA genes and arsenite transporter genes. Phylogenetic discrepancies could be detected in 8 ACR3(2) and 1 arsB (Fig. 4): (i) Aeromonas spp. TS26, TS36 belonging to $\gamma$-Proteobacteria based on 16S rDNA analysis were assigned to the $\beta$-Proteobacteria based on Acr3p(2) sequences; (ii) Stenotrophomonas spp. TS28, SY2, SY1 belonging to $\gamma$-Proteobacteria using $16 \mathrm{~S}$ rDNA analysis were assigned to $\alpha$-Proteobacteria based on $\operatorname{Acr} 3 \mathrm{p}(2)$ sequences; (iii) Comamonas sp. TS32, TS35 and Delftia sp. TS33 were shown to belong to $\beta$-Proteobacteria, but were assigned to the $\gamma$-Proteobacteria clade using Acr3(2)p sequences; (iv) LY4 belonged to $\alpha$-Proteobacteria based on the 16S rRNA gene, but its ArsB was in $\gamma$-Proteobacteria clade (Fig. 4). The phylogenetic discrepancies exhibited that these 9 arsenite transporter genes were probably acquired by horizontal gene transfer (HGT). Furthermore, 6 of these horizontally transferred ACR3(2) genes were from the strains isolated from the highly arsenic-contaminated TS soil.

\section{Discussion}

The first goal of this study was to determine the distribution and diversity of arsenite-resistant bacteria from soils with different levels of arsenic contamination. In addition, the ability to oxidize arsenite was further analyzed. Since the soils were collected from the surface and subsurface zones, only aerobic conditions were used in bacterial isolation. Thus, only aerobic/facultative aerobic bacteria were obtained in this study. We identified Acinetobacter, Comamonas, Pseudomonas, Stenotrophomonas, Delftia, Agrobacterium, and Bacillus as the major genera of arseniteresistant bacteria in the four arsenic-contaminated soils. 


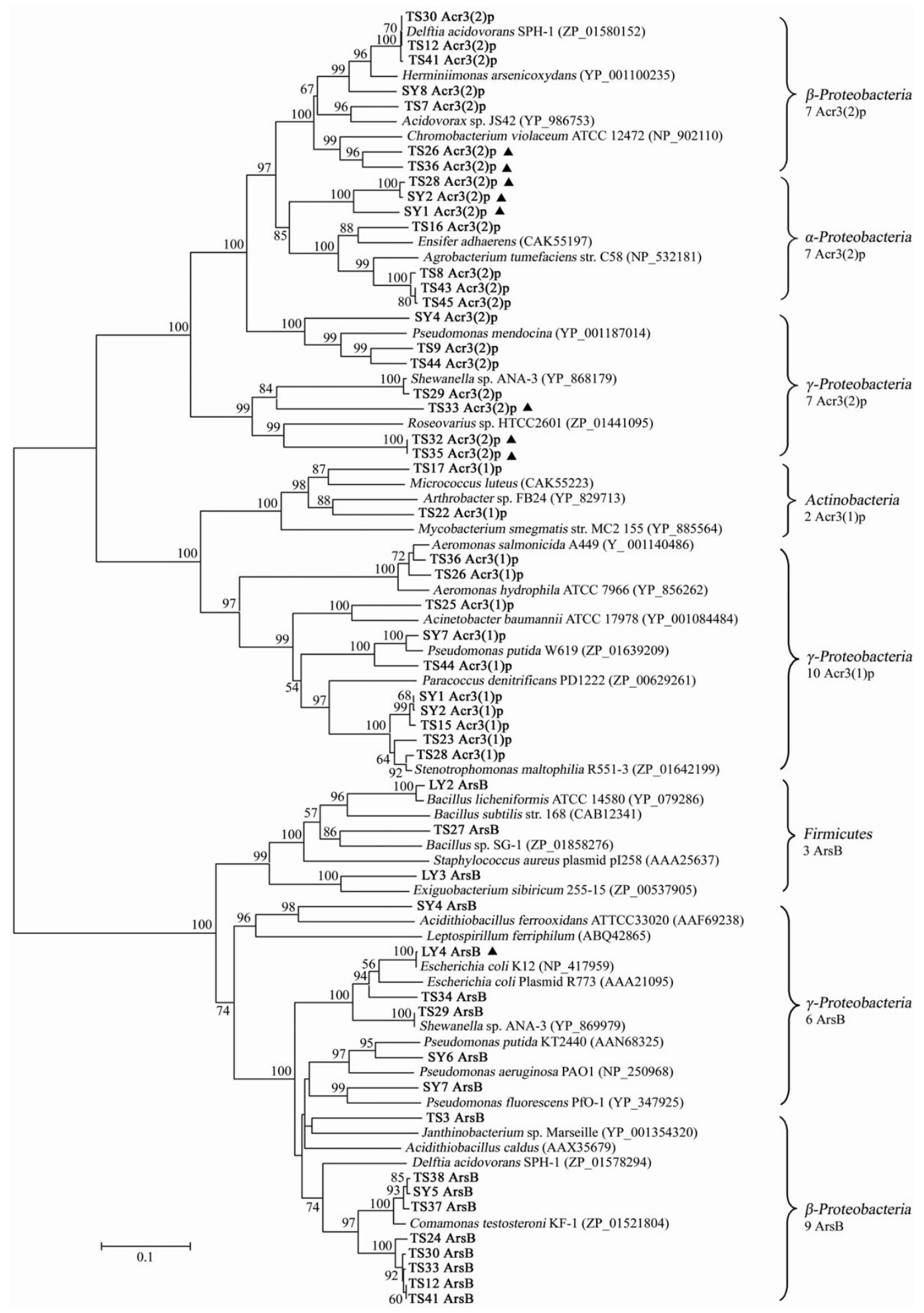

Figure 3

Phylogenetic tree of arsenite transporters [ArsB/Acr3(I)p/Acr3(2)p]. Phylogenetic analysis of the deduced amino acid sequences ( $230 \mathrm{aa}$ ) of arsB/ACR3(I)/ACR3(2)genes. Filled triangles, potential horizontally transferred arsenite transporter genes. Sequences in this study are in bold type and bootstrap values over $50 \%$ are shown. The scale bar 0.1 shows $10 \%$ aa sequence substitution. 


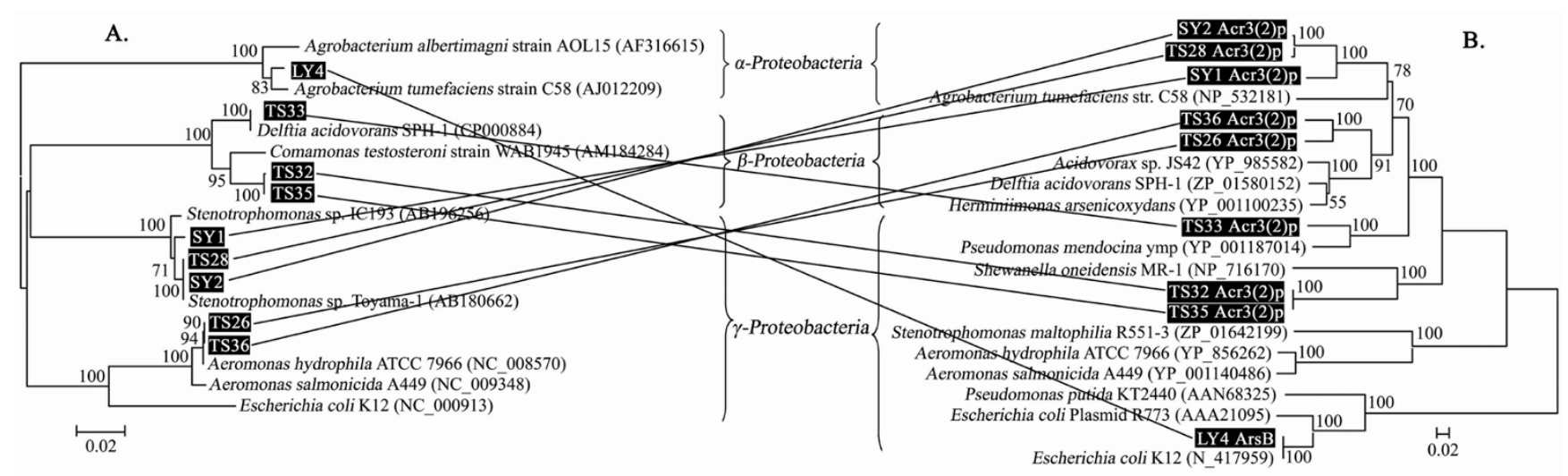

Figure 4

Phylogenetic evidence of potential HGT of arsB/ACR3(2). Phylogenetic comparison between I6S rRNA genes (A) and potential horizontally transferred arsB/ACR3(2) genes (B). All sequences used in A's and B's construction are subsets of Fig. I and Fig. 3 respectively.

Among them, Acinetobacter, Agrobacterium, Bacillus, and Pseudomonas species were commonly found at other arsenic-contaminated sites $[16,29,30,32-35]$. To our knowledge, Janibacter, Micrococcus, Thauera, and Williamsia were novel arsenite-resistant bacteria isolated in this study.

We found that the high arsenic TS site revealed a much higher diversity of arsenite-resistant bacteria and the resistance levels observed were also much higher than in isolates found in the intermediate and low arsenic-contaminated sites. It is a limitation that only one medium (CDM) was used for bacterial isolation which could result in the observed differences between sites. The 12 strains with arsenite MICs $>20 \mathrm{mM}$ were all obtained from the high arsenic soil. Generally, it has been proposed that high arsenic contamination is likely to exert a strong selective pressure leading to low microbial diversity [16,32]. However, the TS site used in our study had several hundred years of smelting history [36] which may result in the evolution of more bacterial species that were already well adapted at elevated arsenic concentrations. Moreover, Pennanen et al. [37] reported that at long-term field sites, soil microbial communities have had time to adapt to metal and/or metalloid stress. Turpeinen et al. [33] also found that the diversity of arsenic-resistant bacteria in higher arsenic-, chromium- and copper-contaminated soil was higher than that in less contaminated soil. These results suggested that microorganisms had been adapted to high arsenic stress and maintained their diversity in TS site after a long-term exposure to arsenic.

The aox $B$ genes were detected in all of the five arsenite oxidizers but not in the non-arsenite oxidizers. This indicates that $a \circ x B$ may be specific for most of the aerobic arseniteoxidizing bacteria and useful for detecting arsenite-oxidiz- ing microorganisms in the environment. Inskeep et al. [15] reported that arsenite oxidase genes are widely present in different arsenite oxidizers and widespread in soil-water systems. We have enriched pristine soils with arsenite to isolate arsenite-oxidizing bacteria from noncontaminated soils but without success. To our knowledge, all of the cultured arsenite oxidizers obtained so far were isolated from arsenic-contaminated sites. Inskeep et al. [15] detected aoxB-like sequences from arsenic-contaminated environments but not from pristine soils indicating that arsenite oxidation is a major process in arseniccontaminated environments. The expression level of aoxB could probably be applied to monitor environmental arsenic-contaminated levels.

A phylogenetic analysis of the 5 arsenite oxidizers based on the 16S rRNA genes and the aoxB genes showed a similar phylogeny indicating genomic stability of the aoxB genes. The MICs of the arsenite oxidizers displayed a maximal arsenite resistance level in both Pseudomonas and Agrobacterium. Furthermore, strains containing both the arsenite oxidase and any type of transporter gene showed a higher arsenite resistance level. These results suggest that bacteria capable of both arsenite oxidation and arsenite efflux mechanisms have an elevated arsenite resistance level. We also found that arsenite can be fully oxidized even at concentrations close to the MIC in arsenite oxidizers SY8 and TS44 (data not shown). Recently, we have amplified and sequenced the arsC/ACR3 operon $\left(\operatorname{ars}_{1} \mathrm{C}^{-}\right.$ $\operatorname{arsR}$ - $\operatorname{ars} \mathrm{C}_{2}$-ACR3-ars $H$ ) in the adjacent downstream region of aoxB in Pseudomonas. sp. TS44 (data not shown; GenBank, EU311944). Kashyap et al. [31] found that in Agrobacterium tumefaciens strain $5 \mathrm{~A}$, disruption of aoxR caused a loss in the ability to oxidize arsenite and furthermore resulted in an apparent reducing phenotype probably due to the action of cytosolic ArsC and subsequent pumping 
out of As(III). It is noteworthy to point out that there are two processes of $\mathrm{As}(\mathrm{V})$ reduction in the environment. One is the use of $\mathrm{As}(\mathrm{V})$ as a terminal electron acceptor under anaerobic conditions. The other is the intracellular reduction of $\mathrm{As}(\mathrm{V})$ to $\mathrm{As}(\mathrm{III})$ under aerobic conditions due to the ArsC-dependent cytoplasmic arsenate reduction as part of the arsenic resistance system (ars operon). Since As(III) is the species being pumped out of cell (by arsB or $A C R 3)$, the presence of As(III) in the environments can also be detected under aerobic condition.

One of the main purposes in this research was to determine the correlation among the bacterial arsenite resistance level, bacterial distribution in the environment and the different types of arsenite transporter gene families. We found that the ACR3 genotypes were predominant over arsB (33 ACR3 vs. 18 ars B) in our samples which was in agreement with a report by Achour et al. [16]. In addition, we found any two types of arsenite transporter genes can coexist in the same strain [arsB and ACR3(1), arsB and ACR3(2), ACR3(1) and ACR3(2)]. Related reports also found the presence of multiple sets of arsenic resistance genes and operons in one strain, especially the arsenite transporter genes. Pseudomonas putida KT2440 contains two operon clusters (arsRBCH) for arsenic resistance [38]. Acidithiobacillus caldus has three sets of arsenic resistance determinants, one located on the chromosome and the other two exist on the transposon $[39,40]$. Corynebacterium glutamicum has two typical arsenic-resistant operons and additional ars $B$ and ars $C$ genes, of which two arsenite transporter genes belonged to the ACR3(1) group [41]. The genome of Herminiimonas arsenicoxydans revealed the presence of four arsenic resistance operons including two ars $B$ genes and one ACR3 [42]. Multiple sets of arsenic resistance determinants were also reported in $B$. subtilis [18] and Desulfovibrio desulfuricans G20 [43]. These findings indicate that microorganisms have acquired multiple resistance determinants via chromosomal duplication or horizontal gene transfer to cope with arsenic toxicity. In this study, ACR3(1) and ACR3(2) appeared to be mostly associated with high arsenite resistance since they were only identified from the high and intermediate arseniccontaminated sites, while ars $B$ was found in all three sites. One explanation is that ACR3 may have a higher affinity and velocity to extrude arsenite than ars $B$ and thus seems to be more effective.

Heavy metal contaminated environments were shown to provide a strong selective pressure for transfer of related resistance genes within soil systems [44]. In this study, aoxB and $A C R 3(1)$ appeared to be more stable than $A C R 3(2)$ and ars $B$ since phylogenetic discrepancies between 16S rRNA genes and ACR3(2)/arsB were found which supported HGT events of ACR3(2) and arsB. Most of the HGT occurred in strains identified from the highly arsenic-contaminated TS soil [6 ACR3(2)]. This indicates that arsenite transporter genes may be horizontally transferred and increasingly present in a microbial population under conditions of long-term elevated arsenic stress. It is important to note that HGT occurred in somewhat closely related species in this study, however, this does not detract from the suggestion of HGT and it is likely that the HGT events occurred between these closely related species. Martinez et al. [45] reported that $\mathrm{P}_{\mathrm{IB}}$-Type ATPases ( $p b r A$ / cadA/zntA) were broadly transferred in Arthrobacter and Bacillus in radionuclide and metal contaminated soils. Jackson and Dugas [46] also suggested that horizontally transferred $\operatorname{ars} C$ resulted in the diversities and complexities of arsenate reductase during its evolution. Excluding $\operatorname{ars} C$, other genes related to arsenic resistance (e.g. $\operatorname{ars} A$, arsB/ACR3) had not been reported as being transferred by HGT. To our knowledge, this is the first study to report widespread horizontal transfer of arsenite transporter genes. The HGT event and subsequent maintenance may have occurred increasingly under the high arsenic pressure [47] and resulted in plastic changes in microbial diversity.

\section{Conclusion}

This work investigates the distribution and diversity of microbial arsenite-resistant species in soils representing three different levels of arsenic contamination, and further studies the arsenite resistance and arsenic transforming genes of these species. Our research provides valuable information of microbial species and genes responsible for arsenite oxidation and resistance, and increases knowledge of the diversity and distribution of the indigenous bacteria that may be stimulated for successful bioremediation of arsenic contamination.

\section{Methods \\ Site description and soil sample collection}

Four soil samples representing high (TS), intermediate (SY) and low (LY/YC) levels of arsenic contamination were used in this study. The TS soil was collected in Tieshan District, a highly arsenic-contaminated region, which is located in Huangshi City, Hubei Province, central China. There are several kinds of metal (gold, copper, iron) mines that have been smelted for many years. Concentrations of arsenic and heavy metals are extremely high in water, soil and sediments of this area [36]. The SY soil was collected from a pig farm, Shayang County, Jingmen City, Hubei Province where there are certain levels of arsenic in the soil due to the long-term usage of arsenic in feed material to resist disease and stimulate pig growth. The other two samples, LY and YC, were collected from the low arsenic-contaminated soils near the Yellow Sea of Lianyungang and Yancheng Cities Jiangsu Province, eastern China, respectively. 
Several soil samples from each site were collected from the surface horizon $(0-15 \mathrm{~cm})$, stored at $4^{\circ} \mathrm{C}$ and mixed together for bacterial isolation. The total arsenic concentrations of the four soils (determined by atomic absorption spectrometry) were $337.2 \mathrm{mg} \mathrm{kg}^{-1}$ (183.4-882.2 mg $\left.\mathrm{kg}^{-1}, \mathrm{SD}=184.58\right), 72.1 \mathrm{mg} \mathrm{kg}^{-1}\left(43.4-94.6 \mathrm{mg} \mathrm{kg}^{-1}, \mathrm{SD}=\right.$ $18.31), 24.1 \mathrm{mg} \mathrm{kg}^{-1}\left(15.7-40.1, \mathrm{mg} \mathrm{kg}^{-1}, \mathrm{SD}=8.24\right)$ and $34.6 \mathrm{mg} \mathrm{kg}^{-1}\left(22.0-48.8 \mathrm{mg} \mathrm{kg}^{-1}, \mathrm{SD}=8.96\right)$ for TS, SY, LY and $\mathrm{YC}$, respectively.

\section{Isolation and identification of arsenite-resistant and arsenite-oxidizing bacteria}

One hundred grams of each soil sample was amended with $\mathrm{NaAsO}_{2}$ to a final concentration of $500 \mathrm{mg} \mathrm{kg}^{-1}$ and incubated at $28^{\circ} \mathrm{C}$ for a week. During incubation sterilized $\mathrm{H}_{2} \mathrm{O}$ was added to the jars to reach the original moisture value. Isolation of arsenite-resistant bacteria was performed by adding $10 \mathrm{~g}$ (triplicates) of each soil to 90 $\mathrm{mL} 0.85 \% \mathrm{NaCl}$ in a $250 \mathrm{~mL}$ Erlenmeyer flask and shaken at $160 \mathrm{rpm}$ for $30 \mathrm{~min}$. $1 \mathrm{~mL}$ of the above mixture was added to $9 \mathrm{~mL} 0.85 \% \mathrm{NaCl}$ for serial dilution and plated on chemically defined medium (CDM) plates [9] with a final concentration of $800 \mu \mathrm{M} \mathrm{NaAsO}$ and incubated at $28^{\circ} \mathrm{C}$ for another week. Single colonies were picked and restreaked several times to obtain pure isolates.

The obtained arsenite-resistant bacteria were tested for their abilities to oxidize $\mathrm{As}(\mathrm{III})\left(\mathrm{NaAsO}_{2}\right)$ using a qualitative $\mathrm{KMnO}_{4}$ screening method [10]. Each arsenite-resistant bacterium was inoculated in CDM broth with a final concentration of $800 \mu \mathrm{M} \mathrm{NaAsO}$ and then shaken at 160 rpm for 5 days at $28^{\circ} \mathrm{C}$. For each isolate $1 \mathrm{~mL}$ culture was added to a $1.5 \mathrm{~mL}$ centrifuge tube containing $30 \mu \mathrm{L}$ of $0.01 \mathrm{M} \mathrm{KMnO}_{4}$ and the color change of $\mathrm{KMnO}_{4}$ was monitored. A pink color of the mixture indicated a positive arsenite oxidation reaction [formation of As(V)]. The sterile CDM medium containing the same amount of $\mathrm{NaAsO}_{2}$ was used as an abiotic control. The arsenite oxidizing phenotype was also detected using the molybdene blue method with a spectrophotometer (DU800, BeckMan, CA, USA) [48].

Total DNA of each strain was extracted using standard molecular genetic methods. Nearly full-length 16S rDNA of the bacteria was amplified by PCR using universal primers Uni-27F and Uni-1492R (Table 1) [49]. PCR amplification was performed in an ATC 201 Thermal Cycler (Apollo, San Diego, CA, USA) in a $50 \mu \mathrm{L}$ volume containing 10-50 ng DNA, 1 ng $\mu \mathrm{L}^{-1}$ of each primer, 200 $\mu \mathrm{M}$ of each dNTP, $2.5 \mathrm{mM} \mathrm{MgCl}_{2}, 2.5 \mu \mathrm{L}$ dimethyl sulfox-

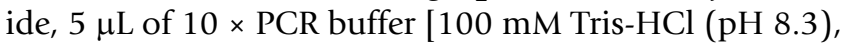
$100 \mathrm{mM} \mathrm{KCl}$ ] and 2.5 units of Taq DNA polymerase (Fermentas, Hanover, MD, USA), and adding $\mathrm{ddH}_{2} \mathrm{O}$ to a final volume of $50 \mu \mathrm{L}$. The PCR program consisted of an initial 5 min denaturation step at $94^{\circ} \mathrm{C} ; 30$ cycles of $1 \mathrm{~min}$ at $94^{\circ} \mathrm{C}, 1 \mathrm{~min}$ at $50^{\circ} \mathrm{C}, 1.5 \mathrm{~min}$ at $72^{\circ} \mathrm{C}$; and a final extension step at $72^{\circ} \mathrm{C}$ for $5 \mathrm{~min}$.

Colony morphologies and 16S rDNA PCR-RFLP technique were used to remove the repeated isolates for each sample. PCR-RFLP was performed by enzyme digestion at $37^{\circ} \mathrm{C}$ for $3 \mathrm{hrs}$ in a $20 \mu \mathrm{L}$ volume containing $2 \mu \mathrm{L}$ of $10 \times$ enzyme buffer, 2.5 units of HaeIII or MspI and 5-10 $\mu \mathrm{L}$ of the $16 \mathrm{~S}$ rDNA PCR products, amending $\mathrm{dd}_{2} \mathrm{O}$ to a final volume of $20 \mu \mathrm{L}$. The digested DNA fragments were separated in 2\% agarose gels and the digestion patterns were grouped by DNA fingerprinting profiles.

\section{Identification of the aox $B$ gene encoding the arsenite oxidase Mo-pterin subunit and arsB, ACR3(I) and ACR3(2) genes encoding different arsenite transport proteins}

The PCR amplification of aoxB was performed using degenerate primers (Primers \#1F and \#1R) (Table 1) and following the PCR conditions as described by Inskeep et al. [15]. The amplification of $\operatorname{arsB}, A C R 3(1)$ and $A C R 3(2)$ genes were performed using three pairs of degenerate primers [darsB1F and darsB1 $\mathrm{R}$ for $\operatorname{ars} B$, dacr1F and dacr1 $\mathrm{R}$ for ACR3(1), dacr5F and dacr4R for ACR3(2)] (Table 1) as

Table I: Primers used in this study

\begin{tabular}{llc}
\hline Primer & Sequence & Reference \\
\hline Uni-27F & 5'-AGAGTTTGATCMTGGCTCAG-3' & 49 \\
Uni-I492R & 5'-GGYTACCTTGTTACGACTT-3' & \\
Primers \#IF & 5'-GTSGGBTGYGGMTAYCABGYCTA-3' & 15 \\
Primers \#IR & 5'-TTGTASGCBGGNCGRTTRTGRAT-3' & 16 \\
darsBIF & 5'-GGTGTGGAACATCGTCTGGAAYGCNAC-3' & 16 \\
darsBIR & 5'-CAGGCCGTACACCACCAGRTACATNCC-3' & \\
dacrIF & 5'-GCCATCGGCCTGATCGTNATGATGTAYCC-3' & 16 \\
dacrIR & 5'-CGGCGATGGCCAGCTCYAAYTTYTT-3' & 16 \\
dacr5F & 5'-TGATCTGGGTCATGATCTTCCCVATGMTGVT-3' & \\
\hline
\end{tabular}

$\mathrm{B}=\mathrm{G}, \mathrm{T}$ or $\mathrm{C} ; \mathrm{M}=\mathrm{A}$ or $\mathrm{C} ; \mathrm{N}=\mathrm{A}, \mathrm{C}, \mathrm{G}$, or $\mathrm{T} ; \mathrm{R}=\mathrm{A}$ or $\mathrm{G} ; \mathrm{S}=\mathrm{G}$ or $\mathrm{C} ; \mathrm{V}=\mathrm{A}, \mathrm{C}$, or $\mathrm{G} ; \mathrm{Y}=\mathrm{C}$ or $\mathrm{T}$. 
described by Achour et al. [16]. The PCR products were purified using the Gel Extraction Kit (SBS Genetech, Shanghai, China). The purified PCR products were ligated into pGEM-T (Promega, Madison, WI, USA) and the ligation products were used to transform E. coli DH5 $\alpha$ competent cells by electroporation. The transformants were grown on LB agar containing ampicillin, X-Gal and IPTG at $37^{\circ} \mathrm{C}$ for $16 \mathrm{hrs}$ according to the manufacturer's recommendations.

\section{DNA sequencing and phylogenetic analysis}

The PCR products were purified using the UltraPure ${ }^{\mathrm{TM}}$ PCR Kit (SBS Genetech). DNA sequencing analysis was performed using ABI 3730XL DNA analyzer by Sunbiotech company (Beijing, China). All sequences were analyzed by BlastN (for 16S rRNA gene) and BlastX (for deduced AoxB and ArsB/Acr3p) searching tools [50]. All sequences were checked manually and edited for the same lengths using ClustalX 1.83 software [51]. MEGA 3.1 software [52] was used to construct phylogenetic trees by the neighbor-joining distance method [53] and reliability of inferred trees was tested with 1000 bootstrap replicates. Some reference sequences from the GenBank were used in constructing phylogenetic trees for clarification.

\section{Determination of the minimal inhibitory concentrations (MICs) of arsenite}

The MIC, defined as the lowest concentration of arsenite that inhibited growth in CDM broth, was performed with all arsenite-resistant bacteria. Triplicate samples of each single colony were inoculated in $3 \mathrm{~mL}$ CDM broth supplemented with increasing concentrations of $\mathrm{NaAsO}_{2}$, incubated with shaking at $28^{\circ} \mathrm{C}$ for one week and the $\mathrm{OD}_{600}$ values were determined. The initial screening for MICs was performed with $5 \mathrm{mM}, 10 \mathrm{mM}, 15 \mathrm{mM}$, and $20 \mathrm{mM}$ of $\mathrm{NaAsO}_{2}$. Subsequent determinations were performed with $1 \mathrm{mM} \mathrm{NaAsO}$ intervals over the appropriate range. The sensitivity of MIC detection was $1 \mathrm{mM}$.

\section{Nucleotide sequence accession numbers}

The nucleotide sequences are posted in the NCBI GenBank database. Their accession numbers are: EU073067EU073124 for 16S rRNA genes, EF523515, EU311944EU311947 for $a \circ x B$, and EU311948-EU311999 for arsB/ ACR3.

\section{Authors' contributions}

All authors participated in the design of the study and data analyses. LC carried out samples collection, bacterial isolation and drafted the manuscript, participated in molecular genetic studies. GL carried out molecular genetic studies and construction of phylogenetic trees. CR participated in the design of the experiments and helped to draft the manuscript. GW is the Principal Investigator of the funded projects. She coordinated the study and helped to draft the manuscript. All authors read and approved the final manuscript.

\section{Acknowledgements}

This work was supported by the National Natural Science Foundation of China (30570058); The PhD Supervisor Fund (20060504027) and the

Retuning Oversea Scientist Fund of the Ministry of Education, P. R of China.

\section{References}

I. Sun G: Arsenic contamination and arsenicosis in China. Toxicol Appl Pharmacol 2004, 198(3):268-27I.

2. Valls M, de Lorenzo V: Exploiting the genetic and biochemical capacities of bacteria for the remediation of heavy metal pollution. FEMS Microbiol Rev 2002, 26(4):327-338.

3. Silver S, Phung LT: A bacterial view of the periodic table: genes and proteins for toxic inorganic ions. J Ind Microbiol Biotechnol 2005, 32(II-1 2):587-605.

4. Simeonova DD, Micheva K, Muller DA, Lagarde F, Lett MC, Groudeva $\mathrm{VI}$, Lievremont $\mathrm{D}$ : Arsenite oxidation in batch reactors with alginate-immobilized ULPAs I strain. Biotechnol Bioeng 2005, 9 I(4):44|-446.

5. Lievremont D, N'Negue MA, Behra P, Lett MC: Biological oxidation of arsenite: batch reactor experiments in presence of kutnahorite and chabazite. Chemosphere 2003, 5 I (5):4l 9-428.

6. Turner AW: Bacterial oxidation of arsenite. I. Description of bacteria isolated from arsenical cattle-dipping fluids. Aust $J$ Biol Sci 1954, 7(4):452-478.

7. Osborne $\mathrm{FH}$, Enrlich $\mathrm{HL}$ : Oxidation of arsenite by a soil isolate of Alcaligenes. J Appl Bacteriol 1976, 4 I (2):295-305.

8. Bruneel O, Personne JC, Casiot C, Leblanc M, Elbaz-Poulichet F, Mahler BJ, Le Fleche A, Grimont PA: Mediation of arsenic oxidation by Thiomonas sp. in acid-mine drainage (Carnoules, France). J Appl Microbiol 2003, 95(3):492-499.

9. Weeger W, Lievremont D, Perret M, Lagarde F, Hubert JC, Leroy M, Lett MC: Oxidation of arsenite to arsenate by a bacterium isolated from an aquatic environment. BioMetals 1999, I2(2): | $4 \mid$ |- 149.

10. Salmassi TM, Venkateswaren K, Satomi M, Nealson KH, Newman DK, Hering JG: Oxidation of arsenite by Agrobacterium albertimagni, AOLI5, sp nov., isolated from Hot Creek, California. Geomicrobiol J 2002, 19(1):53-66.

II. Gihring TM, Druschel GK, McCleskey RB, Hamers RJ, Banfield JF: Rapid arsenite oxidation by Thermus aquaticus and Thermus thermophilus: field and laboratory investigations. Environ Sci Technol 200I, 35( 19):3857-3862.

12. Mukhopadhyay R, Rosen BP, Phung LT, Silver S: Microbial arsenic: from geocycles to genes and enzymes. FEMS Microbiol Rev 2002, 26(3):3।I-325.

13. Silver S, Phung LT: Genes and enzymes involved in bacterial oxidation and reduction of inorganic arsenic. Appl Environ Microbiol 2005, 7 I (2):599-608.

14. Santini JM, Hoven RN vanden: Molybdenum-containing arsenite oxidase of the chemolithoautotrophic arsenite oxidizer NT26. J Bacteriol 2004, 186(6):1614-1619.

15. Inskeep WP, Macur RE, Hamamura N, Warelow TP, Ward SA, Santini JM: Detection, diversity and expression of aerobic bacterial arsenite oxidase genes. Environ Microbiol 2007, 9(4):934-943.

16. Achour AR, Bauda P, Billard P: Diversity of arsenite transporter genes from arsenic-resistant soil bacteria. Res Microbiol 2007, 158(2): : 28-137.

17. Rosen BP: Biochemistry of arsenic detoxification. FEBS Lett 2002, 529(I):86-92.

18. Rosen BP: Families of arsenic transporters. Trends Microbiol 1999, 7(5):207-212.

19. Wu J, Tisa LS, Rosen BP: Membrane topology of the ArsB protein, the membrane subunit of an anion-translocating ATPase. J Biol Chem 1992, 267( ( 8): 1 2570-1 2576.

20. Meng YL, Liu Z, Rosen BP: As(III) and Sb(III) uptake by GIpF and efflux by ArsB in Escherichia coli. J Biol Chem 2004, 279(18): 18334-|834I.

21. Liu Z, Shen J, Carbrey JM, Mukhopadhyay R, Agre P, Rosen BP: Arsenite transport by mammalian aquaglyceroporins AQP7 and AQP9. Proc Natl Acad Sci USA 2002, 99(9):6053-6058. 
22. Walmsley AR, Zhou T, Borges-Walmsley MI, Rosen BP: Antimonite regulation of the $A T P a s e$ activity of ArsA, the catalytic subunit of the arsenical pump. Biochem J 200 I, 360(Pt 3):589-597.

23. Wysocki R, Clemens S, Augustyniak D, Golik P, Maciaszczyk E, Tamas MJ, Dziadkowiec D: Metalloid tolerance based on phytochelatins is not functionally equivalent to the arsenite transporter Acr3p. Biochem Biophys Res Commun 2003, 304(2):293-300.

24. Sato $T$, Kobayashi $Y$ : The ars operon in the skin element of Bacillus subtilis confers resistance to arsenate and arsenite. J Bacteriol 1998, I80(7): |655-166I.

25. Wysocki R, Bobrowicz P, Ulaszewski S: The Saccharomyces cerevisiae ACR3 gene encodes a putative membrane protein involved in arsenite transport. I Biol Chem 1997, 272(48):3006I-30066.

26. Lopez-Maury L, Florencio FJ, Reyes JC: Arsenic sensing and resistance system in the cyanobacterium Synechocystis sp. strain PCC 6803. J Bacteriol 2003, I 85( I 8):5363-537I.

27. Oremland RS, Stolz JF, Hollibaugh JT: The microbial arsenic cycle in Mono Lake, California. FEMS Microbiol Ecol 2004, 48(I): I 5-27.

28. Santini JM, Sly LI, Wen AM, Comrie D, De Wulf-Durand P, Macy JM: New arsenite-oxidizing bacteria isolated from Australian gold mining environments - Phylogenetic relationships. Geomicrobiol ] 2002, I 9(I):67-76.

29. Macur RE, Jackson CR, Botero LM, McDermott TR, Inskeep WP. Bacterial populations associated with the oxidation and reduction of arsenic in an unsaturated soil. Environ Sci Technol 2004, 38(I): 104-III.

30. Chang JS, Yoon IH, Kim KW: Isolation and ars detoxification of arsenite-oxidizing bacteria from abandoned arsenic-contaminated mines. J Microbiol Biotechnol 2007, I 7(5):8I2-82I.

31. Kashyap DR, Botero LM, Franck WL, Hassett DJ, McDermott TR Complex regulation of arsenite oxidation in Agrobacterium tumefaciens. J Bacteriol 2006, I 88(3): |08|-1088.

32. Jackson CR, Harrison KG, Dugas SL: Enumeration and character ization of culturable arsenate resistant bacteria in a large estuary. Syst Appl Microbiol 2005, 28(8):727-734.

33. Turpeinen R, Kairesalo T, Haggblom MM: Microbial community structure and activity in arsenic-, chromium- and coppercontaminated soils. FEMS Microbiol Ecol 2004, 47(I):39-50.

34. Pepi M, Volterrani M, Renzi M, Marvasi M, Gasperini S, Franchi E, Focardi SE: Arsenic-resistant bacteria isolated from contaminated sediments of the Orbetello Lagoon, Italy, and their characterization. J Appl Microbiol 2007, I 03(6):2299-2308.

35. Anderson CR, Cook GM: Isolation and characterization of arsenate-reducing bacteria from arsenic-contaminated sites in New Zealand. Curr Microbiol 2004, 48(5):34I-347.

36. Zhang $X$, Hu Ma, Zhao $Y$, Zhao B: A survey of heavy metals pollution in Daye Tieshan Area. Environ Sci Technol (China) 2005:40-43.

37. Pennanen T, Frostegard A, Fritze H, Baath E: Phospholipid Fatty Acid Composition and Heavy Metal Tolerance of Soil Microbial Communities along Two Heavy Metal-Polluted Gradients in Coniferous Forests. Appl Environ Microbiol 1996, 62(2):420-428.

38. Canovas D, Cases I, de Lorenzo V: Heavy metal tolerance and metal homeostasis in Pseudomonas putida as revealed by complete genome analysis. Environ Microbiol 2003, 5(1 2): I242-1256.

39. Kotze AA, Tuffin IM, Deane SM, Rawlings DE: Cloning and charac terization of the chromosomal arsenic resistance genes from Acidithiobacillus caldus and enhanced arsenic resistance on conjugal transfer of ars genes located on transposon TnAtcArs. Microbiology 2006, I 52(Pt I 2):355 I-3560.

40. Tuffin IM, de Groot P, Deane SM, Rawlings DE: An unusual Tn2 Ilike transposon containing an ars operon is present in highly arsenic-resistant strains of the biomining bacterium Acidithiobacillus caldus. Microbiology 2005, I 5 I (Pt 9):3027-3039.

41. Ordonez E, Letek M, Valbuena N, Gil JA, Mateos LM: Analysis of genes involved in arsenic resistance in Corynebacterium glutamicum ATCC 13032. Appl Environ Microbiol 2005 , 7I(10):6206-62I5.

42. Muller D, Medigue C, Koechler S, Barbe V, Barakat M, Talla E, Bonnefoy V, Krin E, Arsene-Ploetze F, Carapito C, Chandler M, Cournoyer B, Cruveiller S, Dossat C, Duval S, Heymann M, Leize E, Lieutaud A, Lievremont D, Makita Y, Mangenot S, Nitschke W, Ortet P, Perdrial N, Schoepp B, Siguier P, Simeonova DD, Rouy Z, Segurens
B, Turlin E, Vallenet D, Van Dorsselaer A, Weiss S, Weissenbach J, Lett MC, Danchin A, Bertin PN: A tale of two oxidation states: bacterial colonization of arsenic-rich environments. PLOS Genet 2007, 3(4):e53.

43. Li X, Krumholz LR: Regulation of arsenate resistance in Desulfovibrio desulfuricans $\mathbf{G} 20$ by an arsRBCC operon and an ars $C$ gene. J Bacteriol 2007, I 89( I 0):3705-37 I I

44. Ryan RP, Ryan DJ, Dowling DN: Multiple metal resistant transferable phenotypes in bacteria as indicators of soil contamination with heavy metals. J Soil Sed 2005, 5(2):95-100.

45. Martinez RJ, Wang Y, Raimondo MA, Coombs JM, Barkay T, Sobecky PA: Horizontal gene transfer of $P_{1 B}$-type ATPases among bacteria isolated from radionuclide- and metal-contaminated subsurface soils. Appl Environ Microbiol 2006, 72(5):3|| $|-3| \mid 8$

46. Jackson CR, Dugas SL: Phylogenetic analysis of bacterial and archaeal ars $C$ gene sequences suggests an ancient, common origin for arsenate reductase. BMC Evol Biol 2003, 3: I8.

47. Rensing C, Newby DT, Pepper IL: The role of selective pressure and selfish DNA in horizontal gene transfer and soil microbial community adaptation. Soil Biol Biochem 2002 , 34(3):285-296.

48. Lenoble V, Deluchat V, Serpaud B, Bollinger JC: Arsenite oxidation and arsenate determination by the molybdene blue method. Talanta 2003, 6 I (3):267-276.

49. Wilson KH, Blitchington RB, Greene RC: Amplification of bacterial I6S ribosomal DNA with polymerase chain reaction. J Clin Microbiol 1990, 28(9): 1942-1946.

50. BLAST [http://www.ncbi.nlm.nih.gov/BLAST/]

51. Thompson JD, Gibson TJ, Plewniak F, Jeanmougin F, Higgins DG: The CLUSTAL $X$ windows interface: flexible strategies for multiple sequence alignment aided by quality analysis tools. Nucleic Acids Res 1997, 25(24):4876-4882

52. Kumar S, Tamura K, Nei M: MEGA3: Integrated software for Molecular Evolutionary Genetics Analysis and sequence alignment. Brief Bioinform 2004, 5(2): I 50- 163.

53. Saitou N, Nei M: The neighbor-joining method: a new method for reconstructing phylogenetic trees. Mol Biol Evol 1987, 4(4):406-425.

Publish with Biomed Central and every scientist can read your work free of charge

"BioMed Central will be the most significant development for disseminating the results of biomedical research in our lifetime. "

Sir Paul Nurse, Cancer Research UK

Your research papers will be:

- available free of charge to the entire biomedical community

- peer reviewed and published immediately upon acceptance

- cited in PubMed and archived on PubMed Centra

- yours - you keep the copyright 